\title{
Development of Ctenocephalides felis felis (Siphonaptera: Pulicidae) in different substrates for maintenance under laboratory conditions
}

\author{
Desenvolvimento de Ctenocephalides felis felis (Siphonaptera: Pulicidae) em \\ diferentes substratos para manutenção em condições laboratoriais
}

\author{
Gabriela Pereira Salça de Almeida1; Diefrey Ribeiro Campos'; Barbara Rauta de Avelar; \\ Thalita Xavier de Araújo da Silva'; Monique Morais Lambert²; Mariana Silva Revoredo Alves²; Thaís Ribeiro Correia ${ }^{3 *}$ [D \\ 'Discente do Programa de Pós-graduação em Ciências Veterinárias, Universidade Federal Rural do Rio de Janeiro - UFRRJ, Seropédica, RJ, Brasil \\ ${ }^{2}$ Médico Veterinário Autônomo; Universidade Federal Rural do Rio de Janeiro - UFRRJ, Seropédica, RJ, Brasil \\ ${ }^{3}$ Departamento de Parasitologia Animal, Universidade Federal Rural do Rio de Janeiro - UFRRJ, Seropédica, RJ, Brasil
}

How to cite: Almeida GPS, Campos DR, Avelar BR, Silva TXA, Lambert MM, Alves MSR, et al. Development of Ctenocephalides felis felis (Siphonaptera: Pulicidae) in different substrates for maintenance under laboratory conditions. Braz J Vet Parasitol 2020; 29(2): e022819. https://doi.org/10.1590/S1984-29612020047

\begin{abstract}
The aim of this study was to evaluate the efficiency of different substrates for larval development of Ctenocephalides felis felis during its biological cycle. Eight hundred eggs of $C$. felis felis from a flea maintenance colony were used. Different diets were formulated, in which the main substrates were meat flour, powdered milk, sugar, lyophilized bovine blood, tick metabolites and lyophilized egg. The flea eggs were placed in test tubes (10 per tube) and approximately $2 \mathrm{~g}$ of the diet to be tested was added to each tube. There were 10 replicates for each substrate. After 28 days, each tube was evaluated individually for the presence of pupae and emerged adults. The following percentages of the larvae completed the cycle to the adult stage: $67 \%$ in diets containing tick metabolites; $55 \%$, meat flour; $39 \%$, dehydrated bovine blood; $14 \%$, powdered milk; and less than $1 \%$ in diets containing sugar, lyophilized bovine blood, lyophilized egg or wheat bran. It was concluded that among the diets tested, the one constituted by tick metabolites as the substrate was shown to be the most satisfactory for maintaining a laboratory colony of $C$. felis felis, followed by the one containing meat flour.
\end{abstract}

Keywords: Biology, diet, cat flea.

\begin{abstract}
Resumo
Este trabalho teve como objetivo avaliar a eficiência de diferentes substratos no desenvolvimento larval de Ctenocephalides felis felis durante seu ciclo biológico. Foram utilizados 800 ovos de C. felis felis, oriundos de colônia de manutenção de pulgas. Diferentes dietas foram formuladas, contendo como substratos principais a farinha de carne, leite em pó, açúcar, sangue bovino liofilizado, metabólitos de carrapato e ovo liofilizado. Foram distribuídos 10 ovos por tubo de ensaio, aos quais foram acrescidos as dietas a serem testadas, realizando-se 10 repetições para cada substrato. Após 28 dias, cada tubo foi avaliado individualmente pela presença de pupas e adultos emergidos. Nas dietas que continham metabólitos de carrapato, $67 \%$ das larvas completaram o ciclo até a fase adulta; $55 \%$ nas que continham farinha de carne; $39 \%$ contendo sangue bovino desidratado; $14 \%$ com leite em pó, e menos de $1 \%$ em dietas contendo açúcar, sangue bovino liofilizado, ovo liofilizado e farelo de trigo. Concluise que, entre as dietas testadas, a constituída por metabólitos de carrapato como substrato, mostrou-se a mais satisfatória para a manutenção de colônia laboratorial de C.felis felis, seguida da que continha farinha de carne.
\end{abstract}

Palavras-chave: Biologia, dieta, pulga-do-gato. 


\section{Introduction}

Ctenocephalides felis felis is a cosmopolitan parasite of dogs and cats. It is a hematophagous insect of worldwide importance (Rust \& Dryden, 1997) that produces type I hypersensitivity reactions through its bite. It has the capacity to transmit bacteria and viruses such as Bartonella henselae and the feline parvovirus through inoculation of saliva at the time of feeding (Bowman, 2010). Moreover, it is a potential vector for feline hemoplasmosis. The action of flea can lead its host to present severe anemia due to hematophagy in cases of great infestation (Dryden, 1993). It is also an intermediate host for helminths, such as the zoonotic cestode Dipylidium caninum (a parasite of dogs and cats) and the filarial nematode Acanthocheilonema reconditum (syn. Dipetalonema reconditum) (Taylor et al., 2017).

The flea cycle includes egg, larval (three larval instars), pupal and adult stages. It is completed in approximately 21 days and can vary according to temperature, humidity and food availability for the larvae (Linardi et al. 1997).

When the larvae of $C$. felis felis are subjected to environmental conditions, they survive through feeding on organic material. The main substrate that they use consists of the metabolites of adult fleas (Dryden, 1993). Under laboratory conditions, these substrates need to provide the components that are essential for good larval development and to aid in formation of the pupal cocoon, given that fleas may be cannibalistic and feed on eggs of their own species (Lawrence \& Foil, 2002). Thus, for larval nutrition, the metabolites of fleas have been replaced by dehydrated animal blood, as described by Linardi et al. (1997). Other elements such as sand and wheat bran have been added to provide resistance to the pupal cocoon, which is primarily formed by third-stage larvae (Richman et al., 1999).

Experimental colonies of $C$. felis felis enable advances in knowledge of the biology of this species and recognition of weak points in its biological cycle and the potential for becoming a vector for pathogens. Through in vitro and in vivo tests, it becomes possible to unravel the elements that might help in biological control over this ectoparasite and in diminishing its pathogenic potential. To make such advances viable, its cycles needs to be developed efficaciously in a controlled environment, so that all of its stages of life become available for conducting experiments on them (Correia et al., 2003).

The aim of the present study was to evaluate combinations of different substrates for maintaining the larvae of $C$. felis felis under laboratory conditions.

\section{Material and Methods}

In order to perform the proposed experiment, 800 eggs of $C$. felis felis were used. They came from a laboratory colony of fleas that has been maintained using cats and for which approval had been granted by the Ethics Committee for Use of Animals of the Veterinary Institute of the Federal Rural University of Rio de Janeiro, under the protocol number 091/2014.

Different diets were formulated in the proportions of wheat bran, the substrate to be analyzed (which had previously been ground up) and the sand. Thus, a ratio of 1:1:5 for the components, respectively, was maintained. The following substrates were used: meat flour, powdered milk, sugar, lyophilized bovine blood, tick metabolites and lyophilized egg. These were compared with a control diet composed of dehydrated blood that had been used by Vieira et al. (2010), as previously described by Correia et al. (2003). In addition, to determine the importance of a protein compound in the larval diet, a diet containing only wheat bran and sand was prepared, in the proportions of 1:5. All the compounds had previously been ground up and sieved to improve the homogeneity of the diets. All the substrates that were chosen, with the exception of those composed of bovine blood and tick metabolites, were manufactured substrates that are easily found in food stores. The Rhipicephalus sanguineus metabolites that were used were supplied by the same laboratory where the flea colony was maintained.

Ten replicates for each substrate were prepared. The flea eggs were placed in test tubes (10 per tube) and approximately $2 \mathrm{~g}$ of the diet to be tested was added to each tube. The tubes were properly sealed using tissue-non-tissue (TNT) and elastic. They were then incubated in a horizontal orientation, in a climate-controlled chamber with biochemical oxygen demand, at a temperature of $27 \pm 1{ }^{\circ} \mathrm{C}$ and relative humidity of $75 \pm 10 \%$. After 28 days, each tube was individually evaluated for the presence of pupae (Figure 1) and any adults that had emerged. The entire content of each tube was fixed $\left(70^{\circ} \mathrm{GL}\right)$ and was evaluated under a stereoscopic microscope. The criterion used was quantification of the number of adults that had emerged, in each replicate, for each substrate.

The statistical analysis was performed using the Bioestat software, version 5.3, taking the significance level to be 5\% (Ayres et al., 2007). The data were analyzed regarding normal distribution using D'Agostino test $(p<0.05)$. 


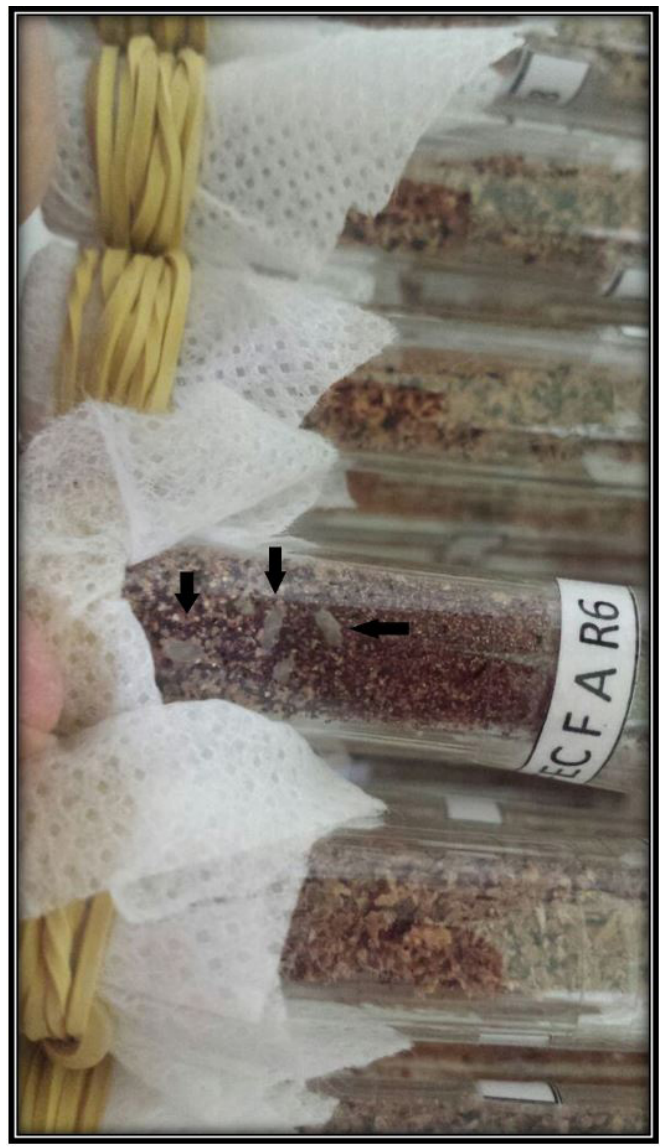

Figure 1. Observation of the presence of pupae during an evaluation of the tubes.

As the data did not present a normal distribution (non-parametric), they were submitted to analysis of variance using the Kruskal-Wallis test followed by Dunn's method to compare the means between the different groups.

\section{Results and Discussion}

The results obtained showed that the mean emergence rate for adults of $C$. felis felis whose larvae had been fed with two grams of the diet containing tick feces was $67 \%$, while it was $55 \%$ when the diet contained meat flour. The emergence rate was 39\% when the diet contained dehydrated bovine blood (Table 1).

According to Dryden (1993), the hematophagous habit of fleas, especially females, which have high intake of blood, leads to release of a good proportion of the ingested blood in their feces. After deposition in the environment, these metabolites are used as food by the larvae of fleas, thereby aiding in their survival. However, quantitative recovery of these metabolites is not sufficiently simple to make it viable to maintain colonies solely using this substrate.

To feed the larvae in laboratories, the feces of fleas are replaced by dehydrated bovine blood. Although bovine blood is most used for the diet of these larvae, blood from other animals can also be used (Linardi et al., 1997).

Several studies have focused on making comparisons of animal blood as the main food source for maintaining flea colonies. Bruce (1948) reported using beer yeast in association with blood components for improving the development of larvae of $C$. felis felis. and evaluated the effects of blood diets from the blood of different animal species. Likewise, in the present study, the possibility of using other food sources that might be as effective as blood for the development of larvae was investigated.

The emergence rate for adult fleas whose larvae were fed with diets containing powdered milk was $14 \%$. The results were unsatisfactory when the larvae were fed with diets containing sugar, lyophilized bovine blood, lyophilized egg or wheat bran, with emergence rates less than or equal to $1 \%$. There was no statistically significant difference among this last group of compounds. 
Table 1. Evaluation of different substrates for maintenance of Ctenocephalides felis felis larvae under controlled condition.

\begin{tabular}{|c|c|c|c|c|c|c|c|c|}
\hline \multirow{2}{*}{ Repetitions } & \multicolumn{8}{|c|}{ Number of emerged adults / Larval substrate } \\
\hline & DBB $^{1}$ & $\mathbf{L E}^{2}$ & $\mathrm{TM}^{3}$ & $S^{4}$ & $\mathrm{MP}^{5}$ & $\mathrm{MF}^{6}$ & WB $^{7}$ & LBB $^{8}$ \\
\hline R1 & 2 & 0 & 6 & 0 & 0 & 3 & 0 & 1 \\
\hline $\mathrm{R} 2$ & 2 & 0 & 9 & 0 & 1 & 8 & 1 & 0 \\
\hline R3 & 2 & 0 & 7 & 0 & 0 & 8 & 0 & 0 \\
\hline R4 & 2 & 0 & 3 & 0 & 1 & 5 & 0 & 0 \\
\hline R5 & 4 & 0 & 6 & 0 & 0 & 6 & 0 & 0 \\
\hline R6 & 8 & 0 & 7 & 0 & 3 & 5 & 0 & 0 \\
\hline $\mathrm{R} 7$ & 4 & 0 & 8 & 0 & 3 & 5 & 0 & 0 \\
\hline R8 & 5 & 0 & 7 & 0 & 2 & 4 & 0 & 0 \\
\hline R9 & 3 & 0 & 9 & 0 & 1 & 7 & 0 & 0 \\
\hline R10 & 7 & 0 & 5 & 0 & 3 & 4 & 0 & 0 \\
\hline Emergency (\%) & 39 & 0 & 67 & 0 & 14 & 55 & 1 & 1 \\
\hline Average & $3.9 a$ & $\mathrm{Obc}$ & $6.7 a$ & Obd & 1.4abcd & $5.5 a$ & $0.1 b$ & $0.1 \mathrm{~b}$ \\
\hline SD & 2.2 & 0.0 & 1.8 & 0.0 & 1.3 & 1.7 & 0.3 & 0.3 \\
\hline
\end{tabular}

1'Dehydrated bovine blood; ${ }^{2}$ Lyophilized egg; ${ }^{3}$ Tick metabolites; ${ }^{4}$ Sugar; ${ }^{5}$ Milk powder; ${ }^{6}$ Meat flour; ${ }^{7}$ Wheat bran; ${ }^{8}$ Lyophilized bovine blood; All diets have sand in their composition. Means followed by the same letter on the line do not differ statistically from each other.

In the samples containing powdered milk and lyophilized egg, presence of fungus was observed in $100 \%$ of the replicates. This may have been related to the high hygroscopic power of these substrates, which would contribute towards changing the medium and favor growth of these microorganisms. For this reason, despite having an emergence rate that did not differ statistically from the substrate used as a control, the potential of powdered milk as a colony-supporting substrate cannot be really evaluated.

Tick metabolites (feces) obtained the best adult emergence rate observed in the present study and it was the first time that they were used as a substrate to maintain a laboratory colony of $C$. felis felis. This can be attributed to the fact that these metabolite were from a hematophagous ectoparasite with similarities to fleas, which in its natural environment uses feces from adult fleas to complete its cycle (Dryden, 1993). However, the use of the tick metabolite becomes an alternative when colonies of fleas and ticks are kept concurrently in the same laboratory, and can generate a destination for this excrement that is normally discarded. Although in natural conditions, the larvae preferentially feed on the feces of adult fleas, they also feed on other organic matter found in the environment. When it comes to maintaining an experimental colony kept in controlled conditions, the number of hatching eggs is higher than what occurs in natural conditions, so the amount of flea feces collected together with the material becomes insufficient for the development of all larval forms, which can lead to death and or cannibalism of these larvae.

Meat flour can also be considered an effective source of nutrients: not only for maintaining hematophagous dipterans, as observed previously (Macedo et al., 2005), but also for larvae of C. felis felis, as it did not differ statistically from tick metabolites and dehydrated bovine blood.

Thus, the diet for the larvae of fleas that contained tick metabolites, followed by the diet with meat flour, showed satisfactory performance for maintaining laboratory colonies of $C$. felis felis, as well as dehydrated bovine blood, which did not differ statistically from each other.

\section{References}

Ayres M, Ayres M Jr, Ayres DL, Santos AS. Bioestat 5.0 - aplicações estatísticas nas áreas das ciências biológicas e médicas. Sociedade Civil Mamirauá/Imprensa Oficial do Estado do Pará; 2007.

Bowman DD. Georgis Parasitologia Veterinária. 9th. ed. Rio de Janeiro: Elsevier; 2010. 
Bruce WN. Studies on the biological requirements of the cat flea. Ann Entomol Soc Am 1948; 41(3): 346-352. http://dx.doi. org/10.1093/aesa/41.3.346.

Correia TR, Souza CP, Fernandes JI, Martins IVF, Santos HD, Scott FB. Ciclo biológico de Ctenocephalides felis felis (Bouché, 1835) (Siphonaptera, Pulicidae) a partir de diferentes dietas artificiais. Rev Bras Zoociênc 2003; 5(2): 153-160.

Dryden MW. Biology of fleas of dogs and cats. Compend Contin Educ Pract Vet 1993; 15(4): 567-579.

Lawrence W, Foil LD. The effects of diet upon pupal development and cocoon formation by the cat flea (Siphonaptera: pulicidae). J Vector Ecol 2002; 27(1): 39-43. PMid:12125871.

Linardi PM, De Maria M, Botelho JR. Effects of larval nutrition on the postembryonic development of Ctenocephalides felis felis (Siphonaptera: pulicidae). J Med Entomo/ 1997; 34(4): 494-497. http://dx.doi.org/10.1093/jmedent/34.4.494. PMid:9220685.

Macedo DM, Chaaban A, Moya Borja GE. Desenvolvimento pós-embrionário de Stomoxys calcitrans (Linnaeus, 1758) (Diptera: Muscidae) criadas em fezes de bovinos tratados com diferentes avermectinas. Rev Bras Parasitol Vet 2005; 14(2): 45-50. PMid:16153344.

Richman DL, Koehler PG, Brenner RJ. Spray dried bovine blood: an effective laboratory diet for Ctenocephalides felis felis (Siphonaptera: Pulicidae). J Med Entomol 1999; 36(3): 219-221. http://dx.doi.org/10.1093/jmedent/36.3.219. PMid:10337086.

Rust MK, Dryden MK. The biology, ecology and management of the cat flea. Annu Rev Entomol 1997; 42(1): 451-473. http://dx.doi. org/10.1146/annurev.ento.42.1.451. PMid:9017899.

Taylor MA, Coop RL, Wall RL. Parasitologia veterinária. Rio de Janeiro: Guanabara Koogan; 2017.

Vieira VPC, Fazio PI Jr, Verocai GG, Correia TR, Scott FB. Avaliação de diferentes dietas merídicas sobre a emergência de adultos de Ctenocephalides felis felis (Siphonaptera: pulicidae). Rev Bras Parasito/ Vet 2010; 19(1): 65-67. http://dx.doi.org/10.1590/S198429612010000100013 . PMid:20385063. 